\title{
UJI DAYA ANTIHELMINTIK EKSTRAK ETANOL $70 \%$ BAWANG PUTIH (Allium sativum L.) TERHADAP CACING Ascaridia galli In vitro
}

\author{
Yusmira $\mathbf{G}^{1}$, Isti’anah $S^{2}$ \\ ${ }^{1}$ Mahasiswa Fakultas Kedokteran Universitas Islam Indonesia \\ ${ }^{2}$ Departemen Parasitologi Fakultas Kedokteran Universitas Islam Indonesia
}

\begin{abstract}
ABSTRAK
Prevalensi penyakit Askariasisdi Indonesia masih cukup tinggi, terutama pada anak-anak.Penyakit ini juga memiliki dampak merugikan, sehingga diperlukan usaha untuk mengatasi infeksi Ascaris lumbricoides. Penggunaan obat cacing di masyarakat masih belum optimal, sehingga perlu adanya alternatif pengobatan lain untuk penyakit ini. Bawang putih (Allium sativum L.) mengandung saponin dan flavonoid yang diduga memiliki efek antihelmintik. Mengetahui daya antihelmintik ekstrak etanol 70\% bawang putih (Allium sativum L.) terhadap cacing Ascaridia galli In vitro.Penelitian merupakan eksperimental laboratoris.Ekstrak etanol 70\% bawang putih (Allium sativum L.) terdiri atas 4 konsentrasi 100\%, 50\%, 25\% dan 12,5\% dengan empat kali replikasi. Pada setiap kelompok perlakuan dimasukkan 10 ekor cacing yang diamati kematiannya setiap 1 jam sampai batas maksimal. Data dianalisis menggunakan One Way Anova, dan dilanjutkan dengan analisis probit dilakukan untuk mengetahui LC50, LC90, LT50 dan LT90. Rerata waktu kematian cacing pada konsentrasi 100\%, 50\%, 25\% dan $12,5 \%$ serta kelompok kontrol menunjukkan perbedaan yang bermakna $p=0,000(p<0,05)$ dengan LC50 sebesar 26,852\% dan LC90 sebesar 65,85\%. Pada konsentrasi 100\% ekstrak etanol 70\% bawang putih (Allium sativum) nilai LT50 adalah 3,207 jam dan nilai LT90 adalah 5,481 jam. Ekstrak etanol 70\% bawang putih (Allium sativum L.) memiliki efek antihelmintik terhadap cacing Ascaridia galli in vitro.
\end{abstract}

Kata Kunci : Antihelmintik, Bawang putih (Allium sativum), Ascaridia galli, in vitro

\section{ABSTRACT}

Prevalence of Ascaris lumbricoides infection is still high, especially in children. Because its harmful effect, an effort to overcome Ascaris lumbricoides infection is needed. The use of synthetic helminthes drug by the community is not yet optimal. Garlic (Allium sativum L.) can be used as an alternative drug because it has saponin and flavonoid which is believed in having anthelminthic effect.To understand the anthelminthic effect of $70 \%$ ethanol extract of garlic (Allium sativum L.) against Ascaridia galli In vitro. The study was an experimental study. The experimentusing 70\% ethanol extract garlic (Allium sativum L.) in 4 concentration of 100\%, 50\%, 25\%, and 12,5\% with four times replication. In each experimental group contained 10 helminthes and death of worms assessed for every 1 hour until the maximal experimental time. Data analyzed usingOne Way Anova. Probit analyze using to understand LC50, LC90, LT50, and LT50.The mean death time on experimental group ethanol extract of garlic (Allium sativum L.), concentration 100\%, 50\%, 25\%, and 12,5\%, was having a significant difference with $p=0,0000(p<0,05)$. LC50 of 70\% ethanol extract garlic (Allium sativum L.) was 26,852\% and LC90 was 65,85\%. In their 100\% concentration of 70\% ethanol extract of garlic (Allium sativum L.), the LT50 value was 3,207 hours and LT90 value was 5,481 hours. The70\% ethanol extract of garlic (Allium sativum L.) had anthelmintic effect against Ascaridia galliin vitro.

Key words: Anthelmintic, garlic (Allium sativum L.), Ascaridia galli, in vitro. 


\section{Pendahuluan}

Prevalensi penyakit infeksi di Negaranegara berkembang seperti Indonesia masih cukup tinggi. Hal ini berkaitan dengan kondisi higiene perorangan dan kebersihan sanitasi lingkungan yang belum baik. Penyakit infeksi yang insidensinya masih tinggi adalah cacingan dimana penyakit ini merupakan salah satu penyakit yang berbasis lingkungan (Departemen Kesehatan RI, 2007)

World Health Organization tahun 2006 menyatakan bahwa lebih dari 1 milyar orang terinfeksi cacing Ascaris lumbricoides, 795 juta orang terinfeksi cacing Trichuris trichiura, dan 740 juta orang terinfeksi cacing tambang (Ancylostoma duodenale dan Necator americanus). Bank Data Global WHO tahun 2006 menyatakan bahwa prevalensi cacingan pada anak usia sekolah dasar cukup tinggi yaitu $75 \%$ (WHO, 2006).

Ascariasis adalah penyakit yang disebabkan oleh infeksi cacing Ascaris. Prevalensi askariasis di Indonesia masih cukup tinggi, terutama pada anak. Survei Depkes RI pada anak sekolah dasar pada 27 provinsi di Indonesia pada tahun 2002 hingga 2006 menyatakan bahwa prevalensi Ascaris lumbricoides masih cukup tinggi yaitu sebesar $22,0 \%, 21,7 \%, 16,1 \%, 12,5 \%, 17,8 \%$ (Departemen Kesehatan RI, 2007).

Penyakit Askariasis mempengaruhi pemasukan (intake), pencernaan (digestif), penyerapan (absorbsi), dan metabolisme makanan. Kecacingan dapat menimbulkan kekurangan nutrisi pada tubuh yang dapat berupa kekurangan kalori dan protein serta kehilangan darah. Kecacingan juga dapat dapat menghambat perkembangan fisik, kecerdasan dan produktifitas kerja, serta dapat menurunkan ketahanan tubuh sehingga mudah terkena penyakit lainnya (Surat Keputusan Menteri Kesehatan Republik Indonesia No.424/Menkes/SK/VI.2006).

Obat cacing (antihelmintik) sintetik yang tersedia dan dijual bebas di apotik adalah pirantel pamoat. Masyarakat masih banyak yang belum menggunakan obat tersebut karena harga yang dianggap cukup mahal untuk golongan tertentu yang justru memungkinkan untuk terkena infeksi ini cukup tinggi (Kuswinarti, 1993). Pirantel pamoat bekerja dengan mengakibatkan depolarisasi pada cacing, menyebabkan efek samping mual, muntah dan diare. Penderita Askariasis yang memiliki kelainan hati ataupun ginjal tidak dapat menggunakannya karena antihelmintik ini dimetabolisme dalam hati dan diekskresikan melalui ginjal (Katzung, 2004).

Masih terbatasnya penggunaan obat-obat cacing sintetik oleh masyarakat, maka diperlukan obat alternatif yang menggunakan bahan alam atau biasa disebut dengan pengobatan tradisional yaitu menggunakan bawang putih (Allium sativum L.). Bawang putih mengandung senyawa saponin dan flavonoid yaitu suatu zat yang dapat berperan sebagai antihelmintik (Rahmawati, 2011; Wijayakusuma, 2007). Senyawa tersebut adalah senyawa yang mudah larut dalam pelarut polar sehingga digunakanlah pelarut etanol untuk memisahkan kandungan zat aktif dalam tanaman. Pelarut etanol $70 \%$ digunakan karena dapat melarutkan zat aktif saponin dan flavonoid secara optimal (Djajanegara \& Wahyudi, 2009).

\section{Metode}

Penelitian ini merupakan penelitian eksperimental laboratorium in vitro. Rancangan penelitian yang digunakan adalah rancangan eksperimen sederhana post test only control group design. Subyek pada penelitian ini dibagi menjadi 6 kelompok sebagai berikut: kelompok ekstrak etanol bawang putih (Allium sativum L.) $70 \%$ dengan konsentrasi $100 \%, 50 \%, 25 \%$ $12,5 \%$, kelompok kontrol positif dengan pirantel pamoat $0,236 \%$ dan kelompok kontrol negatif menggunakan $\mathrm{NaCl}$ 0,9\%. Besar sampel untuk setiap perlakuan adalah 10 ekor dengan jumlah replikasi sebanyak 4 kali pengulangan.

Bahan uji yang digunakan adalah bawang putih (Allium sativum) dengan subjek penelitian adalah cacing Ascaridia galli tanpa melihat jenis kelaminnya. Cacing didapatkan dari tempat pemotongan ayam di daerah Terban, Sleman. Cacing yang digunakan yang masih hidup, dilihat dari gerakan cacing yang masih aktif dan memiliki besar yang sama.

Hasil penelitian diukur dari jumlah cacing yang mati dalam $25 \mathrm{ml}$ larutan ekstrak etanol $70 \%$ bawang putih (Allium sativum L.), dihitung setiap 1 jam sampai waktu maksimal pengamatan. Cacing dikatakan mati apabila disentuh tidak bergerak atau tidak memberikan respon.

Penelitian ini melalui 2 tahap, yaitu uji pendahuluan untuk mengetahui rerata lama hidup cacing di luar tubuh hospes pada larutan $\mathrm{NaCl}$ 
0,9\% dan DMSO 1\%. Hasil uji tersebut dijadikan batas waktu maksimal untuk uji utama. Pada uji uji utama setiap kematian cacing dinilai setiap jam sampai batas waktu penelitian dan selanjutnya data rerata waktu kematian cacing dianalisis menggunakan One Way Annova kemudian dilanjutkan dengan uji Post Hoc Test Bonferoni. Analisis probit dilakukan untuk mengetahui LD50, LD90, LT50 dan LT90.

\section{Hasil dan Pembahasan}

Berdasarkan hasil ujian pendahuluan diperoleh rerata waktu kematian cacing adalah 18 jam, sehingga waktu pengamatan dilakukan maksimal selama 18 jam. Hasil uji utama kematian cacing terhadap ekstrak etanol $70 \%$ bawang putih (Allium sativum L.) tersaji dalam Tabel.1

Tabel 1. Rerata waktu kematian cacing Ascaridia galii dalam berbagai kelompok

\begin{tabular}{ccccccc}
\hline \multirow{2}{*}{ Replikasi } & \multicolumn{5}{c}{ Rerata waktu kematian cacing (jam) } \\
\cline { 2 - 7 } & K1 & K2 & K3 & K4 & K5 & K6 \\
\hline I & 3 & 5 & 8 & 13 & 14 & 18 \\
II & 3 & 6 & 8 & 12 & 16 & 17 \\
III & 3 & 6 & 9 & 12 & 15 & 18 \\
IV & 3 & 7 & 9 & 12 & 16 & 18 \\
X & $\mathbf{3}$ & 6 & 8,5 & 12,25 & 15,25 & 17,75 \\
\hline
\end{tabular}

Ket:

K1: Kelompok Pirantel pamoat $0,236 \%$

K2: Konsentrasi $100 \%$ ekstrak etanol 70\% bawang putih (Allium sativum $L$.)

K3: Konsentrasi $50 \%$ ekstrak etanol 70\% bawang putih (Allium sativum L.)

K4: Konsentrasi $25 \%$ ekstrak etanol $70 \%$ bawang putih (Allium sativum L.)

K5: Konsentrasi 12,5 \% ekstrak etanol 70\% bawang putih (Allium sativum L.)

K6: Kelompok $\mathrm{NaCl}$ 0,9 \%

Hasil analisis One Way Anova terhadap rerata waktu kematian cacing pada perlakuan ekstrak etanol $70 \%$ bawang putih (Allium sativum L.) adalah $p=0,000 \quad(\mathrm{p}<0,05)$ berarti terdapat perbedaan yang bermakna terhadap waktu kematian cacing pada kelompok perlakuan. Analisis Post Hoc Test Bonferoni dilanjutkan untuk mengetahui perbedaan kemaknaan pada setiap kelompok perlakuan. Test Bonferroni menunjukkan bahwa rerata waktu kematian cacing antara semua konsentrasi adalah berbeda bermakna dengan $p=0,000$. Hasil analisis probit menunjukkan bahwa $\mathrm{LC}_{50}$ adalah $26,852 \%$ dan $\mathrm{LC}_{90}$ adalah $65,85 \%$.

Tanaman Allium sativum $L$ memiliki kandungan senyawa saponin dan flavonoid yang tinggi (Safagat). Senyawa saponin dan flavonoid yang terkandung didalam umbi bawang putih dapat dimanfaatkan sebagai vermisida (Heronymus, 2007). Cara kerjanya senyawa saponin adalah dengan menurunkan tegangan permukaan (surface tension) dinding membran cacing dan menghambat kerja enzim asetilkolinesterase, sehingga cacing akan mengalami paralisis otot dan berujung pada kematian cacing (Heronymus, 2007). Senyawa ini bersifat toksik tetapi zat ini tidak berbahaya bagi manusia. Nio (1989) mengungkapkan bahwa berat jenis molekul saponin yang tinggi menyebabkan zat ini tidak diabsorbsi oleh tubuh.

Analisis probit LT50 dan LT90 terhadap kematian cacing Ascaridia galli pada ekstrak etanol $70 \%$ bawang putih (Allium sativum) dapat dilihat pada Tabel 2 .

Tabel 2. Tabel Analisis Probit LT 50 dan LT90 pada berbagai konsentrasi

\begin{tabular}{ccc}
\hline Konsentrasi (\%) & LT50 (jam) & LT90 (jam) \\
\hline 100 & 3,207 & 5,481 \\
50 & 4,852 & 8,443 \\
25 & 7,91 & 14,695 \\
12,5 & 9,7 & 17,529 \\
\hline
\end{tabular}

Ket:

LT $=$ Lethal Time

Hasil analisis probit menunjukkan semakin kecil konsentrasi ekstrak etanol $70 \%$ bawang putih (Allium sativum L.), maka semakin lama waktu yang dibutuhkan untuk membunuh cacing. Hal ini diduga disebabkan karena faktor pengenceran yang menyebabkan semakin kecil kadar senyawa aktif pada ekstrak yang diduga mempunyai daya antihelmintik. Penelitian serupa menyatakan ekstrak alkohol Allium sativum dan Piper longum pada liver amphistome Gigantocotyle explanatum memiliki efek paralitik pada konsentrasi 3000 $\mathrm{mg} / \mathrm{ml}$. Ekstrak tersebut dapat menyebabkan paralisis total pada $G$. explanatum dalam waktu 15 menit, sedangkan pada konsentrasi yang lebih 
rendah waktu yang diperlukan untuk paralisis total pada $G$. explanatum adalah lebih dari 15 menit (Sing). Penelitian efek antihelmintik dari minyak umbi bawang putih (Allium sativum L.) terhadap Ascaridia galli dan Heterakis gallinae menunjukkan bahwa pada konsentrasi 2\%, $4 \%$ dan $6 \%$ dapat menyebabkan mortalitas pada cacing setelah tepapar selama 12 jam, 10 jam dan 8 jam (Nagaich, et al., 2000).

\section{Simpulan}

Ekstrak etanol 70\% bawang putih (Allium sativum) memiliki daya antihelmintik terhadap cacing Ascaridia galli) dengan $\mathrm{LC}_{50} 26,852 \%$, $\mathrm{LC}_{90} 65,85 \%, \mathrm{LT}_{50} 3,207 \mathrm{jam}$ dan $\mathrm{LT}_{90} 5,481 \mathrm{jam}$ pada konsentrasi $100 \%, \mathrm{LT}_{50} 4,852$ jam dan $\mathrm{LT}_{90}$ 8,443 jam pada konsentrasi $50 \%, \mathrm{LT}_{50} 7,91$ jam dan $\mathrm{LT}_{90} 14,695$ jam pada konsentrasi $25 \%$, dan $\mathrm{LT}_{50} 9,7$ jam dan $\mathrm{LT}_{90} 17.529$ jam pada konsentrasi $12,5 \%$

\section{Daftar Pustaka}

Departemen Kesehatan RI, 2007. Profil Kesehatan Indonesia 2006. Pusat Data dan Informasi, Jakarta.

Djajanegara, I., Wahyudi, P., 2009. Pemakaian Sel HeLa dalam Uji Sitotoksisitas Fraksi Kloroform dan Etanol Ekstrak Daun Annona squamosa. Jurnal Ilmu Kefarmasian Indonesia. 7(1) : $7-11$.

Hieronymus, 2007. Ragam \& Khasiat Tanaman Obat. Agromedika, Jakarta.
Katzung, B. G. 2004. Farmakologi Dasar dan Klinik. Buku 3 Edisi 8. Jakarta : EGC.

Kuswinarti, 1993. Penelitian In Vitro Terhadap Beberapa Tanaman yang Dikenal Sebagai Obat Cacing. Majalah Kedokteran Bandung. 25 (3) : 100-103.

Nagaich, S., Singh, K., Studies on the anthelmintic activity of Allium sativum (Garlic) oil on common poultry worms Ascaridia galli and Heterakis gallinae. Journal of Parasitology and Applied Animal Biology .2000;9:47-52.

Nio, K.O., 1989. Zat- zat Toksik yang Secara Alamiah Ada Pada Bahan Makanan Nabati. Cermin Dunia Kedokteran no.58(25).

Rahmawati, Y., 2011. Sehat dengan Bumbu Dapur. Prima Pustaka : Yogyakarta

Surat Keputusan Menteri Kesehatan Republik Indonesia No.424/Menkes/SK/VI.2006. Pedoman Pengendalian Cacingan. Depkes: Jakarta.

Singh T.U., Kumar D., \& Tandan S.K.,2008.Paralytic effect of alcoholic extract of Allium sativum and Piper longum on liver amphistome, Gigantocotyle explanatum. Indian $J$ Pharmacol. 2008. 40(2): 64-68

WHO, 2006. Soil Transmitted Helminths. http://www. who.int/intestinal_worms/en/. Diakses pada tanggal 8 Januari 2012.

Wijayakusuma, H. M. 2007. Penyembuhan dengan Bawang Putih dan Bawang Merah. Cetakan I. Jakarta : Sarana Pustaka Prima. 